\title{
AN INDEX TO EVALUATE THE ACCEPTANCE OF SPECIALTY COFFEES IN CONSUMER GROUPS
}

\author{
Mariana Resende ${ }^{1}$, Marcelo Â. Cirillo ${ }^{1 *}$, Flávio M. Borém ${ }^{1}$ \\ ${ }^{1 *}$ Corresponding author. Universidade Federal de Lavras (UFLA)/ Lavras - MG, Brasil. \\ E-mail: macufla@gmail.com | ORCID ID: https://orcid.org/0000-0003-2026-6802
}

\section{KEYWORDS}

models, quality, bootstrap, Acaia, Bourbon.

\begin{abstract}
Numerous factors are related to the individual sensory perception of consumers, which makes it impossible to adapt a model that explains their behavior. In this context and given the scarcity of statistical indexes that evaluate preferences for specialty coffees, new statistical methods should be studied. To this end, our study aimed to create an index that measures the acceptance of specialty coffees. The index was built considering the fit of regression models as a function of principal component scores. Validation was done by significance tests, whose probabilities were obtained by bootstrapping, considering the main measures used in diagnosing outliers as weights, with application to real data from different consumer groups. The coffee varieties Acaia and Bourbon were discriminated in relation to altitude. In conclusion, the index was adequate for the analysis and

characterization of specialty coffees grown at different altitudes.
\end{abstract}

\section{INTRODUCTION}

Consumption and commercialization of coffee produced in Brazil holds a prominent position within the global economic scenario. In this context, numerous factors, such as origin and geographical designation (Ramos et al., 2016), forms of processing (Ribeiro et al., 2019; Ribeiro et al., 2016), specialty coffees and their blends (Paulino et al., 2019), and granulometric classification (Brighenti \& Cirillo, 2019), have been researched as means to improve quality of coffee, aiming to expand the market and acquire new consumers.

An effective market expansion can be achieved by understanding consumer behavior towards preferences and purchase of coffee and its derivatives. Coffee quality analyses are usually based on physical aspects and "cup tasting" trials, which are intrinsic to motivation and social factors that lead Brazilian consumers to enjoy higher quality coffees. In this sense, recent studies have shown concern about behavioral and consumption attitudes (Arruda et al. 2009). Sampaio et al. (2012) noted that knowledge on consumer behavior and habits is considered a positive attribute, as it enables marketing strategies and tactics based on "beliefs" of each consumer group, leading to acceptance or rejection of a product.
Trancoso et al. (2010) provided scientific evidence of an association of usual breakfast consumption with overweight and obesity low risks, besides improving learning ability. Prado et al. (2011) studied consumption habits and preferences for different types of coffee beverages (classified as strictly soft, soft, hard, riada, and rio) among young students in the city of Machado-MG, Brazil. This was a descriptive research, of quantitative nature, to analyze the habits of the interviewed people through questionnaires; it showed that the young people chosen coffees with the best sensory attributes, i.e., soft and strictly soft. In a review study, Rampersaud et al. (2005) found a high prevalence of children and teenagers in the United States and Europe who skip breakfast; their main findings are in agreement with those of Trancoso et al. (2010), who stated that breakfast consumption tends to increase with age (between 18 and 60 years of age) and decrease for children and adolescents (between 4 and 18 years of age).

In terms of coffee quality evaluation by sensory analysis, accuracy of statistical results is related to the fact that both trained tasters and untrained consumers, even with improved sensory skills, are used to discriminate small differences between samples. Consumer groups with

${ }^{1}$ Universidade Federal de Lavras (UFLA)/ Lavras - MG, Brasil.

Area Editor: Luís Carlos Cunha Junior

Received in: 8-28-2019

Accepted in: 6-25-2020 
heterogeneous sensory skills can generate disparate final scores of beverage quality, so more elaborate statistical treatment of results should be employed. Thus, different statistical methods have been applied in studies on consumer attitudes and profiles (Ferreira et al., 2016; Liska et al., 2015; Ossani et al., 2017).

On that basis, our study aimed to propose bootstrap tests to select models used in building preference maps and, thus, formalize a preference index that incorporates the heterogeneous effect of sensory evaluations. We used data from a sensory experiment carried out by a group of consumers, who are differentiated by experience and basic training in tasting specialty coffees.

\section{MATERIAL AND METHODS}

Samples of $100 \%$ Arabica coffee were prepared by removing all defective and roasted beans, respecting a maximum period of 24 hours for tasting. Roasting point was visually determined using a system of color classification with standardized discs (SCAA/Agtron Roast Color Classification System) (SCAA, 2009). With these specifications, four genotypes of specialty coffees (coded as A, B, C, and D; Table 1) were evaluated.

TABLE 1 . Description of the specialty coffees evaluated in sensory analyses by untrained consumers.

\begin{tabular}{cccc}
\hline Type & Genotype & Altitude & Processing \\
\hline A & Yellow Bourbon & above $1200 \mathrm{~m}$ & Natural \\
B & Acaia & below $1100 \mathrm{~m}$ & Peeled Cherry \\
C & Acaia & below $1100 \mathrm{~m}$ & Natural \\
D & Yellow Bourbon & above 1200m & Peeled Cherry \\
\hline
\end{tabular}

Each genotype underwent an acceptance test in two sessions for evaluation of coffee beverage acidity, body, sweetness, and overall score. In the first session, a consumer group (G1) received basic training on coffee tasting, totaling 52 people. In the second session, another consumer group (G2) composed of 47 people received no training, as they were professionals involved in projects related to coffee research and coffee quality.

Each individual received a single sample of each coffee type, whose origin or variety was omitted. For that, a fully randomized experimental model was adopted, and each individual was considered as a replication, and therefore coffee types as treatments.

Following the procedure of Cirillo et al. (2019), data were rescaled considering a matrix $\mathrm{G}_{\mathrm{k}}{ }^{(0)}$, whose element at ij position, described by $\mathrm{g}_{\mathrm{kij}}^{(0)}$, is the response of the $i^{- \text {th }}$ consumer $(i=1, \ldots, N)$ of the $k^{- \text {th }}$ group $(k=1,2)$ about the $\mathrm{j}^{\text {th }}$ variable, i.e., the beverage sensory attribute $(\mathrm{j}$ $=1$, i.e., ..., 4).

Accordingly, vector representation of the $\mathrm{i}^{\text {-th }}$ consumer was rewritten as follows: $\mathrm{G}_{\mathrm{ki}}^{(0)}=\left[\mathrm{G}_{\mathrm{k} 1 \mathrm{j}}^{(0)}, \mathrm{G}_{\mathrm{k} 2 \mathrm{j}}^{(0)}, \ldots, \mathrm{G}_{\mathrm{ki} 4}^{(0)}\right] ;$ and vector of the $\mathrm{j}^{\text {-th }}$ observed variable as: $\mathrm{G}_{\mathrm{kj}}^{(0)}=\left[\mathrm{G}_{\mathrm{k} 1 \mathrm{j}}^{(0)}, \mathrm{G}_{\mathrm{k} 2 \mathrm{j}}^{(0)}, \ldots, \mathrm{G}_{\mathrm{kNj}}^{(0)}\right]$. By keeping these specifications, data rescaling was performed assuming the median (med) of the observed responses in each variable. Thus, the operations used in the rescaling are described in the expressions from (1) to (4):

$\mathrm{g}_{\mathrm{kij}}^{(1)}=\frac{\mathrm{g}_{\mathrm{kij}}^{(0)}-\operatorname{med}\left(\mathrm{g}_{\mathrm{klj}}^{(0)}, \ldots, \mathrm{g}_{\mathrm{kNj}}^{(0)}\right)}{\operatorname{MAD}\left(\mathrm{g}_{\mathrm{k} 1 \mathrm{j}}^{(0)}, \ldots, \mathrm{g}_{\mathrm{kNj}}^{(0)}\right)} ; \mathrm{j}=1, \ldots, 4$ and $\mathrm{k}=1,2$

Where:

The absolute deviation from the median was obtained by (2):

$$
\operatorname{MAD}\left(\mathrm{g}_{\mathrm{k} 1}^{(0)}, \ldots, \mathrm{g}_{\mathrm{kN}}^{(0)}\right)=1,4826 \operatorname{med}_{\mathrm{kj}}\left|\mathrm{g}_{\mathrm{kj}}^{(0)}-\operatorname{med}_{\mathrm{ki}}\left(\mathrm{g}_{\mathrm{ki}}^{(0)}\right)\right| \text {, }
$$

where, 1.4826 is the value corresponding to the $75 \%$ quantile of the standard univariate normal distribution, as suggested by Rousseeuw \& Driessen (1999). Then, assuming $\mathrm{G}_{\mathrm{k}}^{(1)}$ with elements given by $\mathrm{g}_{\mathrm{kij}}^{(1)}$, the covariance matrix was calculated, which resulted in the matrix of eigenvectors of order $r$ defined by $\mathrm{V}$, which enabled obtaining the matrix of the components, according to the following expression: $\mathrm{G}_{\mathrm{k}}^{(2)}=\mathrm{G}_{\mathrm{k}}^{(1)} \times \mathrm{V}$.

Rescaling again, the matrix $\mathrm{G}_{\mathrm{k}}^{(2)}$ was obtained, with each element obtained in (3) with the median absolute deviation estimated in (4).

$$
\begin{aligned}
& \mathrm{g}_{\mathrm{kij}}^{(2)}=\frac{\mathrm{g}_{\mathrm{kij}}^{(1)}-\operatorname{med}\left(\mathrm{g}_{\mathrm{kij}}^{(1)}, \ldots, \mathrm{g}_{\mathrm{kNj}}^{(1)}\right)}{\operatorname{MAD}\left(\mathrm{g}_{\mathrm{kij}}^{(1)}, \ldots, \mathrm{g}_{\mathrm{kNj}}^{(1)}\right)} ; \mathrm{j}=1, \ldots, 4 \text { and } \mathrm{k}=1,2 . \\
& \operatorname{MAD}\left(\mathrm{g}_{\mathrm{k} 1}^{(1)}, \ldots, \mathrm{g}_{\mathrm{kN}}^{(1)}\right)=1,4826 \operatorname{med}_{\mathrm{kj}}\left|\mathrm{g}_{\mathrm{kj}}^{(1)}-\operatorname{med}_{\mathrm{ki}}\left(\mathrm{g}_{\mathrm{ki}}^{(1)}\right)\right| .
\end{aligned}
$$

After applying this procedure for each consumer group (Gk $[\mathrm{k}=1,2]$ ), with the rescaled data (3), the most suitable main components were estimated, using as reference the absolute robust kurtosis (5) for each variable, which was given by $\omega_{j}$.

$\omega_{\mathrm{jk}}=\left|\frac{1}{\mathrm{~N}} \sum_{\mathrm{i}=1}^{\mathrm{N}} \frac{\left[\mathrm{g}_{\mathrm{kij}}^{(2)}-\operatorname{med}\left(\mathrm{g}_{\mathrm{klj}}^{(2)}, \ldots, \mathrm{g}_{\mathrm{kNj}}^{(2)}\right)\right]^{4}}{\left[\operatorname{MAD}\left(\mathrm{g}_{\mathrm{klj}}^{(2)}, \ldots, \mathrm{g}_{\mathrm{kNj}}^{(2)}\right)\right]^{4}}-3\right|, \mathrm{j}=1, \ldots, 4$ and $\mathrm{k}=1,2$

To better interpret these coefficients, a standardization (6) was made so that components associated with higher and lower values, according to Peña \& Prieto (2001), indicate components that best discriminate outliers.

$$
\xi_{\mathrm{kj}}=\frac{\omega_{\mathrm{kj}}}{\sum_{\mathrm{j}=1}^{\mathrm{r}} \omega_{\mathrm{kj}}} \mathrm{k}=1,2
$$


Afterwards, linear (7) and quadratic (8) regression models were adjusted to each set of responses of coffee genotypes, which were coded as A, B, C, and D, and respectively indexed in the models by $\mathrm{c}=1,2,3$, and 4 .

$\mathrm{Y}_{\mathrm{kic}}=\beta_{0}+\beta_{\mathrm{r}} \mathrm{X}_{\mathrm{kric}}+\beta_{\mathrm{s}} \mathrm{X}_{\mathrm{ksic}}+\zeta_{\text {ic }}(\mathrm{i}=1 \ldots \mathrm{N})$ and $(\mathrm{k}=1,2)$

$\mathrm{Y}_{\mathrm{kic}}=\beta_{0}+\beta_{\mathrm{r}} X_{\mathrm{kric}}+\beta_{\mathrm{s}} X_{\mathrm{ksic}}+\beta_{\mathrm{rr}} X_{\mathrm{kric}^{2}}+\beta_{\mathrm{ss}} X_{\mathrm{ksic}}{ }^{2}+\zeta_{\mathrm{ic}}$ $(\mathrm{i}=1 \ldots \mathrm{N})$ and $(\mathrm{k}=1,2)$

In both models, $\mathrm{Y}_{\mathrm{kic}}$ stands for the final scores as a function of the scores of the $\mathrm{i}^{\text {-th }}$ consumer $(\mathrm{i}=1, \ldots, \mathrm{N})$ in the $\mathrm{k}^{\text {th }}$ group $(\mathrm{k}=1,2)$ for the $\mathrm{X}_{\mathrm{kric}}$ and $\mathrm{X}_{\mathrm{ksic}}$ components $(\mathrm{r} \neq \mathrm{s})$ that best discriminate the outliers, which are selected based on the median of the highest estimated standardized kurtosis coefficients (6). Finally, $\zeta_{\mathrm{i}}$ corresponds to the random error associated with each consumer.

For each model, a binary variable $\mathrm{Z}_{\mathrm{kic}}\left(\mathrm{X}_{\mathrm{kric}} \mathrm{X}_{\mathrm{ksic}}\right)$ was calculated (9), as a condition of the expected value of final scores $\mathrm{E}\left(\mathrm{Y}_{\mathrm{kic}}\right)$ for each group and each specialty coffee $(\mathrm{c}=1, \ldots, 4)$.

$Z_{k i c}\left(X_{k r i c}, X_{k s i c}\right)=1$ if $\hat{Y}_{k i c} \geq E\left(Y_{k i c}\right) ; Z_{k i c}\left(X_{k r i c}, X_{k s i c}\right)=0$ if $\hat{Y}_{k i c}<E\left(Y_{k i c}\right)$,

Therefore, a preference index of a given coffee genotype, which was defined as $\mathrm{I}_{\text {pref }}\left(\mathrm{X}_{\mathrm{kric}}, \mathrm{X}_{\mathrm{ksic}}\right)$, was computed according to Menezes et al. (2012), according to (10):

$I_{\text {pref }}\left(X_{\text {ric }}, X_{\text {sic }}\right)=100 \times\left[\frac{\sum_{\mathrm{i}=1}^{N_{k c}} Z_{\text {kic }}\left(X_{\text {kric }}, X_{\text {ksic }}\right)}{N_{\text {kc }}}\right]$ for $\mathrm{k}=1,2 ; c=1,2,3,4$

Where:

$\mathrm{N}_{\mathrm{kc}}$ is the total number of consumers in the $\mathrm{k}^{\text {-th }}$ group who tasted the $\mathrm{c}^{\text {-th }}$ coffee.

Given the preference index (10) computed in both models, the most appropriate model was confirmed based on the lack-of-fit test obtained by the F-statistics

$$
F=\frac{\left(\frac{S Q R_{i}-S Q R_{q}}{d}\right)}{Q M R_{r}}
$$

Where:

$\mathrm{SQR}_{\mathrm{l}}$ and $\mathrm{SQR}_{\mathrm{q}}$ correspond to the sum of linear and quadratic regression models; d, which equals 3 , stands for the difference between the number of parameters of the models (3) and (4), and

$\mathrm{QMR}_{\mathrm{q}}$ is the residual mean square of the quadratic model.

Due to discrepant scores interpreted as outliers, the use of the bootstrap method proposed by Andrade et al. (2014) was required, based on the main model influence measures on calculation of resampling probability for each sample unit. The steps to perform this method are described below:

Step 1: The measure of influence $\left(\left[\mathrm{F}_{\mathrm{ki}}\right] \mathrm{i}=1, \ldots, \mathrm{N}_{\mathrm{k}}\right)$ of the models (7) and (8) was specified. Then, keeping the consumer group $G_{k}(k=1,2)$ fixed for each model, values of $\mathrm{F}_{\mathrm{ki}}$ (DFFits), CovRatio, and Cook's distance were considered.

Step 2: A weight $\mathrm{w}_{\mathrm{i}}\left(\mathrm{i}=1, \ldots, \mathrm{N}_{\mathrm{k}}\right)$ is attributed to each observation, given the following rule:

$$
\text { If } F_{k i} \geq\left|r_{i}\right| \text {, then } w_{i}=\left|F_{i}\right| \text {; if } F_{k i}<\left|r_{i}\right| \text {, then } w_{i}=\left|r_{i}\right| \text {. }
$$

In both situations, $r_{i}$ corresponds to the $i^{- \text {th }}\left(i=1, \ldots, N_{k}\right)$ Studentized residual.

Step 3: Resampling probability $p_{k i}\left(i=1, \ldots, N_{k}\right)$ is calculated

$$
\mathrm{p}_{\mathrm{ki}}=\frac{\mathrm{w}_{\mathrm{ki}}}{\sum_{\mathrm{i}=1}^{\mathrm{n}} \mathrm{w}_{\mathrm{ki}}}
$$

Step 4: The significance probability ( $p$-value) of bootstrap test is calculated with influence measures, using the expression (13) computed in 1000 resampling runs.

$$
\mathrm{p}-\text { value }=\frac{\#\left\{\mathrm{~F}_{\mathrm{b}} \geq \mathrm{F}\right\}}{1000}
$$

Where:

$F_{b}$ corresponds to the non-fit statistics of the $F$ model (11) computed for each generated bootstrap sample and the statistics for the test estimated considering the original sample. The results were obtained using a script in the $\mathrm{R}$ software ( $\mathrm{R}$ Core Team 2019).

\section{RESULTS AND DISCUSSION}

The models used to obtain the preference indices (10) considered the numerical results of sensory evaluation for each consumer group. Table 2 provides the standardized estimates of kurtosis coefficient. 
TABLE 2. Standardized estimates of kurtosis coefficients for the four main components obtained through sensorial evaluations of specialty coffees.

\begin{tabular}{ccccc}
\hline \multicolumn{5}{c}{ Group G1 } \\
\hline Coffee & PC1 & PC2 & PC3 & PC4 \\
\hline A & 0.0027 & $0.7530^{*}$ & $0.2010^{*}$ & 0.0418 \\
B & 0.0000 & $0.0493^{*}$ & $0.9416^{*}$ & 0.0089 \\
C & 0.0005 & $0.5507^{*}$ & $0.4100^{*}$ & 0.0387 \\
D & 0.0003 & $0.2277^{*}$ & $0.6115^{*}$ & 0.1603 \\
\hline Coffee & Group G2 & & PC4 \\
\hline A & PC1 & PC2 $2759^{*}$ & 0.1869 & $0.5310^{*}$ \\
B & 0.0061 & $0.271^{*}$ & $0.3281^{*}$ \\
C & 0.0018 & $0.6137^{*}$ & 0.0562 & $0.0166^{*}$ \\
D & 0.0001 & $0.9716^{*}$ & 0.0114 & 0.0241 \\
\hline
\end{tabular}

*Appropriate components for discrimination of outliers

Based on the results in Table 2, the components used to compose linear (7) and quadratic (8) models were compared by the significance probability (13) of F-statistics (11), which was obtained by bootstrap tests (steps 1-4), considering the influence measurements of CovRatio, Dfits, and Cook mentioned by Weisberg (2005), whose interpretation is given respectively in the following aspect.

When the $\mathrm{i}^{\text {-th }}$ sample observation is removed, the measure of influence by CovRatio allows assessing the impact of such removal regarding the covariance matrix determinant estimate of parameter estimates. For Dfits measure, this impact is evaluated regarding its own predicted value. For Cook's measure, the impact is assessed by the moving away of vector estimates in relation to the parametric values proposed in the regression model.

Considering the use of these measures and comparing them with levels of significance set at 0.05 , 0.10 , and 0.20 , which were used in the non-fit statistics, the results are given in Figure 1.

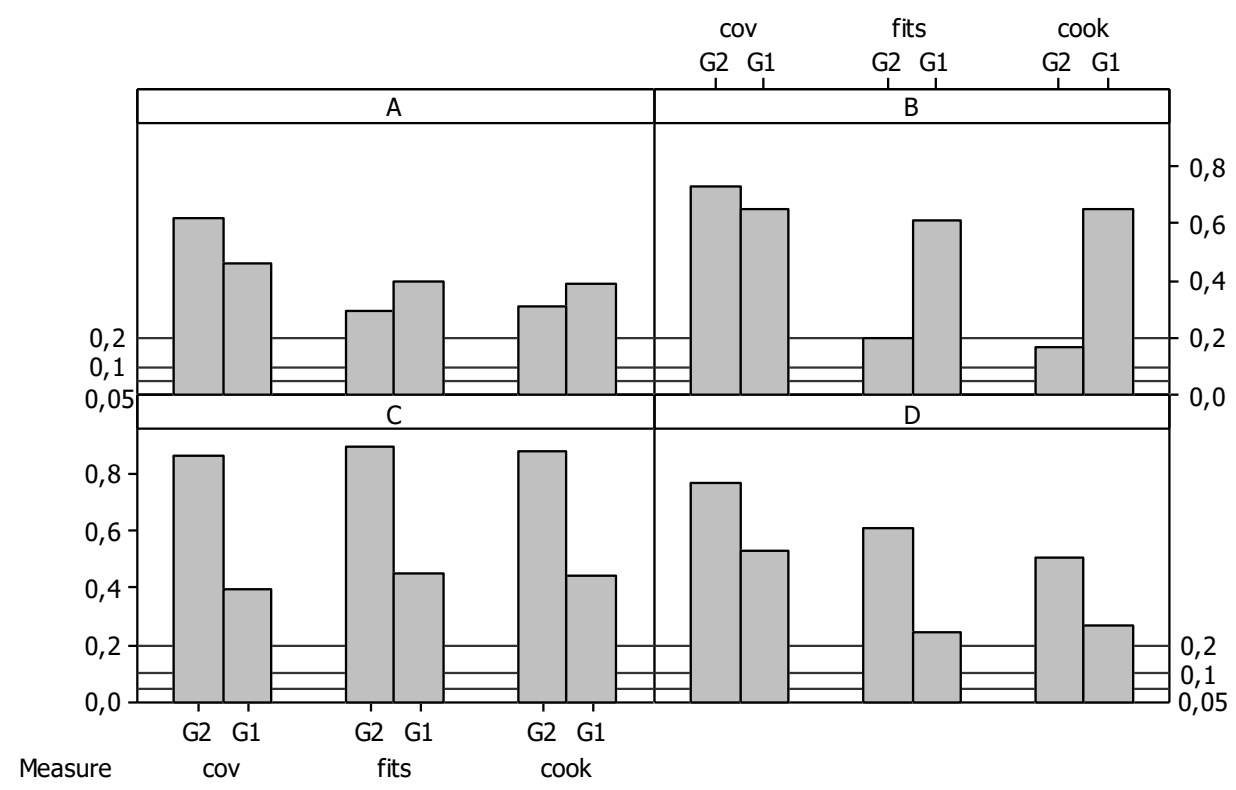

FIGURE 1. Significance probabilities based on the F-statistics considering CovRatio (cov), Dfits (fits), and Cook's distance (Cook) for specialty coffee samples tested by two consumer groups (G1 and G2).

Based on the results in Figure 1 for all specialty coffees evaluated (Table 1) except for the coffee coded as $\mathrm{B}$ in group $\mathrm{G} 2$, when computing probability using the bootstrap test considering Cook's distance as a measure of influence, the quadratic model showed a significance probability greater than 0.20 for all bootstrap tests; therefore, there is statistical evidence indicating that the quadratic model is suitable to be used for the estimation of preference index $\mathrm{I}_{\text {pref }}(10)$.

The specialty coffees $\mathrm{C}$ and $\mathrm{D}$ showed common results, as did the specialty coffees $\mathrm{C}$ and D. The G2 group had a greater significance probability in terms of the suitability of the quadratic model. For coffees A and B, this result was only found for the test when the influence measure by CovRatio was used.

Young people, in particular, have increased consumption and appreciation of superior quality coffees. This can supposedly be explained by different products. According to ABIC (2017), the health benefits of drinking and wide variety of recipes with steamed milk, chocolate sauce, and whipped cream have contributed to such increase in coffee consumption in this age group. 
Moreover, the welcoming atmosphere in coffee shops have encouraged formation of social groups, which have made youngsters both fond and critical of different coffee drinks and blends.

In this regard, in a quantitative survey of consumers within the 20-29 age group, Corrêa (2016) emphasized some facts that certainly influence coffee consumption among young people. Among them are social factors that can exemplified by reference groups, whether at work, family, or social class groups, which influence consumption habits.

Prado et al. (2011) reported that coffee consumption is more common for consumers over 30 years. Based on differences in consumer habits between domestic and foreign markets, specifically European and American, Pires et al. (2003) pointed to a growth in warm drink consumption. This increase was confirmed by Arruda et al. (2009), who performed a study to determine customer profile in different market segments involved in purchasing and consuming coffee and its derivatives.
G2 was formed by consumers with an average age above 30 years and professionals active in coffee research; therefore, these consumers belong to the same segment with a certain peculiarity in terms of coffee preferences.

Arruda et al. (2009) studied coffee consumer and non-consumer behaviors. Among the main results, they observed a relationship between income and coffee preferences. In short, they noted that consumers with higher purchasing power are willing to pay more for upscale products, such as specialty coffees. Thus, it is understandable that consumers over 30 years old are the greatest connoisseurs of superior quality coffees, as they have a more stable financial situation compared to young people.

The results described in Table 3 correspond to the preference index estimates $\left(\mathrm{I}_{\text {pref }}\right)$ considering the original sample and bootstrap samples, which are represented by the CovRatio, DFits, and Cook's tests for G1 and G2. Notably, for comparison, a preference index estimated considering the original sample is also presented using F-statistics.

TABLE 3. Consumer preferences $(\%)$ measured according to the scores of major components that best discriminate outliers.

\begin{tabular}{llcccc}
\hline & & \multicolumn{4}{c}{ Specialty coffee } \\
\hline Group & Test & A & B & C & D \\
\hline \multirow{3}{*}{ G1 } & F & 59.61 & 50.00 & 65.38 & 63.46 \\
& CovRatio & 66.66 & 69.28 & 75.80 & 75.94 \\
& Cook & 60.15 & 65.78 & 67.92 & 73.88 \\
GFits & F & 59.62 & 67.93 & 67.70 & 74.69 \\
& CovRatio & 76.44 & 53.48 & 52.13 & 55.81 \\
& Cook & 71.21 & 52.28 & 54.46 & 64.60 \\
& DFits & 65.67 & 50.62 & 41.32 & 69.81 \\
\hline
\end{tabular}

Special coffee characteristics should be emphasized (Tables 1 and 3), to which the interpretation of preference index results is fundamental. With this focus, we emphasize that the common characteristics between coffee $\mathrm{A}$ and $\mathrm{D}$ are restricted to the fact that yellow Bourbon coffee samples (produced above 1,200 m altitude), regardless of processing type, are characterized by a high sensory quality. In general, when grown in higher altitudes, this coffee variety produces coffee with citric acidity, high sweetness, creamy body, and floral and fruity notes (Borém et al. 2019).

For coffees $\mathrm{B}$ and $\mathrm{C}$, the most relevant characteristics are explained by the fact that these varieties produce red fruits and, mostly, when grown in regions with altitudes lower than $1000 \mathrm{~m}$, result in drinks with lower acidity and less sweetness and complex flavors, predominantly caramel and medium-to-low body flavors (Borém et al. 2019). Quite often these varieties can also produce coffees with a slight astringency. Such sensory profile is closer to the standard known by most Brazilian consumers except for defective coffee consumption.

Comparing the results in G1 (Table 3), the coffees $\mathrm{A}$ and $\mathrm{D}$ were classified in the same variety and produced at an altitude above $1200 \mathrm{~m}$. Regarding sensory properties, both coffees produce drinks with quite diverse flavors and aromas that even untrained consumers are able to identify. Therefore, given their high sensory quality, consumers are expected to have greater preference for them if compared to coffees B and C.

With this expectation, the G1 group showed a greater preference for type D and C coffees. However, when considering a naturally processed coffee, which is characterized by high sweetness, creaminess, and body scores, scores of sensorial evaluations were discrepant since such attributes are usually unknown by untrained or inexperienced consumers, precisely because they present unusual flavors.

In group $\mathrm{G} 2$ preference was for type $\mathrm{A}$ and $\mathrm{D}$ coffees rather than the others. This is consistent with the results found by Barbosa et al. (2012), who stated that environmental interference and geographic origin can influence beverage quality. So, when comparing types $\mathrm{C}$ and D, G2 showed similar preferences, as they are of the same variety and are produced at the same altitude.

\section{CONCLUSIONS}

Given the relationship between consumer preference index and specialty coffee characterization, 
preference can be used in coffee quality analysis, allowing differentiation of consumer groups and incorporation of information into the model related to discrepant evaluations in the generation of indexes.

\section{ACKNOWLEDGMENTS}

The authors would like to thank the National Council for Scientific and Technological Development (Conselho Nacional de Desenvolvimento Científico and Tecnológico - CNPq) for the financial support through research in the project $n^{\circ} 140242 / 2019-8$.

\section{REFERENCES}

ABIC - Associação Brasileira da Indústria de café. Indicadores da indústria de café (2017) Available: https://www.abic.com.br/estatisticas/indicadores-daindustria/indicadores-da-industria-de-cafe-2017/. Acessed: Mar 17, 2020.

Andrade LR, Cirillo MA, Beijo LA (2014) Proposal of a bootstrap procedure using measures of influence in nonlinear regression models with outliers. Acta Scientiarum Technology 36(1):93-99. DOI:

http://dx.doi.org/10.4025/actascitechnol.v36i1.17564

Arruda AC, Minim VAR, Ferreira MAM, Minim LA, Silva NM, Soares CF (2009) Justificativas e motivações do consumo e não consumo de café. Ciência e Tecnologia de Alimentos 29(4):754-763. DOI:

http://dx.doi.org/10.1590/S0101-20612009000400009

Barbosa JN, Borém FM, Cirillo MA, Malta MR, Alvarenga AA, Alves HMR (2012) Coffe Quality and its interactions with environmental factors in Minas Gerais, Brazil. Journal of Agricultural Science 5(4):181-190. DOI: http://dx.doi.org/10.5539/jas.v4n5p181

Borém FM, Cirillo MA, Alves APC, Santos CM, Liska GR, Ramos MF, Lima RR (2019) Coffee sensory quality study based on spatial distribution in the mantiqueira mountain region of Brazil. Journal of Sensory Studies (e12552):1-15. DOI: http://dx.doi.org/10.1111/joss.12552

Brighenti CRG, Cirillo MA (2018) Analysis of defects in coffee beans compared to biplots for simultaneous tables. Revista Ciência Agronômica 49(1):62-69. DOI: http://dx.doi.org/10.5935/1806-6690.20180007

Cirillo M A, Ramos MF, Borém FM, Miranda FM, Ribeiro DE, Menezes FS (2019) Statistical procedure for the composition of a sensory panel of blends of coffee with different qualities using the distribution of the extremes of the highest scores. Acta Scientiarum Agronomy 41(e39332):2-14. DOI:

http://dx.doi.org/10.4025/actasciagron.v41i1.39323

Corrêa AP (2016) A Percepção do Consumidor da Diferenciação entre o Café Tradicional e o Especial. Trabalho de Conclusão de Curso Gestão do Agronegócio, Faculdade de Ciências Aplicadas, Universidade Estadual de Campinas.

Ferreira HA, Liska GR, Cirillo MA, Borém FM, Ribeiro DE, Cortez RM, Guiraldeli CHC (2016) Selecting a probabilistic model applied to the sensory analysis of specialty coffees performed with consumer. Revista IEEE América Latina Transactions 14(3):1507-1512. DOI: http://dx.doi.org/10.1109/TLA.2016.7459642
Liska GR, Menezes FS, Cirillo MA, Borém FM, Cortez RM, Ribeiro DE (2015) Avaliação de painéis sensoriais com consumidores de bebidas de cafés especiais utilizando o método boosting na análise discriminante. Semina.

Ciências Agrárias (Online) 36(6):3671-3679.

DOI: http://dx.doi.org/10.5433/1679-

0359.2015v36n6p3671

Menezes CC, Borges SV, Carneiro J de DS, Cirillo MA, Pinheiro ACM, Oliveira LF (2012) Optimization of Guava (Psidium guajava, $L$ ) preserves using the acceptance test, response surface methodology and preference mapping. Boletim do Centro de Pesquisa e Processamento de Alimentos 30(1):1-10. DOI: http://dx.doi.org/10.5380/cep.v30i1.28654

Ossani PC, Cirillo MA, Borém FM, Ribeiro DE, Cortez RM (2017) Qualidade de cafés especiais: uma avaliação sensorial feita com consumidores utilizando a técnica MFACT. Revista Ciência Agronômica (Online) 48(1):92100. DOI: http://dx.doi.org/10.5935/1806-6690.20170010.

Paulino ALB, Cirillo MA, Ribeiro DE, Borém FM, Matias GC (2019) A mixed model applied to joint analysis in experiments with coffee blends using the least squares method. Revista Ciência Agronômica 50(3):345-352. DOI: http://dx.doi.org/10.5935/1806-6690.20190041

Peña D, Prieto F (2001) Multivariate outlier detection and robust covariance matrix estimation. Technometrics 43(3):286-310. DOI:

http://dx.doi.org/10.1198/004017001316975899

Pires MM, Campos AC, Braga MJ, Rufino JLS (2003)

Impactos do crescimento do consumo de cafés especiais na competitividade inter-regional da atividade cafeeira. Revista de Economia e Sociologia Rural 41(3):53-71. DOI: https://doi.org/10.1590/S0103-20032003000300003

Prado AS, Paiva EFF, Pereira RGFA, Sette RSS, Silva JR, Paiva LC, Barbosa CA (2011) Hábitos de consumo e preferência pelo tipo de bebida do café (Coffea arabica L.) entre jovens de Machado/MG. Coffee Science 6(3):184-192.

R Core Team (2019) R: A language and environment for statistical computing. R Foundation for Statistical Computing. Vienna. Available: http://www.R-project.org/

Ramos M F, Ribeiro DE, Cirillo MA, Borém FM (2016) Discrimination of the sensory quality of the Coffea arabica L. (cv. Yellow Bourbon) produced in different altitudes using decision trees obtained by the CHAID method. Journal of the Science of Food and Agriculture 96(10):3543-3551. DOI: http://dx.doi.org/10.1002/jsfa.7539

Rampersaud GC, Pereira MA, Girard BL, Adams J, Metzl JD (2005) Breakfast habits, nutritional status, body weight, and academic performance in children and adolescents. Journal of the American Dietetic Association 105(5):74360. DOI: http://dx.doi.org/10.1016/j.jada.2005.02.007 
Ribeiro DE, Borém FM, Cirillo MA, Prado MVB, Ferraz VP, Alves HMR, Taveira JH da S (2016) Interaction of genotype, environment and processing in the chemical composition expression and sensorial quality of Arabica coffee. African Journal of Agricultural Research 11(27):2412-2422. DOI:

https://doi.org/10.5897/AJAR2016.10832

Ribeiro BB, de Carvalho AM, Cirillo MA, Câmara FM de M, Montanari FF (2019) Sensory profile of coffees of different cultivars, plant exposure and post-harvest. African Journal of Agricultural Research 14(26):11111120. DOI: https://doi.org/10.5897/AJAR2019.14079

Rousseeuw PJ, Driessen K (1999) Fast algorithm for the minimum covariance determinant estimator.

Technometrics 41(3):212-223. DOI:

http://dx.doi.org/10.1080/00401706.1999.10485670
Sampaio DO, Coelho AL, Gosling M, Fagundes AFA, Sousa CV (2012) O consumidor de café expresso em Minas Gerais: Diferenças, Hábitos e Preferências. Gestão e Regionalidade 28(84):49-60. DOI:

http://dx.doi.org/10.13037/gr.vol28n84.1622

SCAA - Speciality Coffe Association of America (2009) Cupping Specialty Coffee. SCAA, 7 p.

Trancoso SC, Cavalli SB, Proença RPC (2010) Café da manhã: caracterização, consumo e importância para a saúde. Revista Brasileira de Nutrição 23(5):859-869. DOI: http://dx.doi.org/10.1590/S1415-52732010000500016

Weisberg S (2005) Applied linear regression. New York, John Wiley and Sons, 370p. 